Available online/abstracted at http://www.biolineinternational.org.br/njps; www.ajol.info/journals.njps; www.cas.org

\title{
INFLUENCE OF SMOKING ON RESPIRATORY SYMPTOMS AND LUNG FUNCTION INDICES IN SAWMILL WORKERS IN BENIN CITY, NIGERIA.
}

\author{
A. J. UGHEOKE ${ }^{1}$, M. I. EBOMOYI and V. I. IYAWE
}

${ }^{I}$ Department of Medicine, Irrua Specialist Teaching Hospital, Irrua, Edo State, and Department of Physiology, School of Basic Medical Sciences, University of Benin, Benin City, Edo State, Nigeria. Email: maureenebomoyi@yahoo.com Tel: +234 805573 7064, +234 8029501895

Summary: The study was done to assess the influence of smoking on respiratory symptoms and respiratory function in sawmill workers in Benin City. 150 sawmill workers who were all males and aged between 18 and 50 years, and had been in continuous employment in sawmill factories for a minimum of one year were studied. They were selected by a two - stage random sampling process from sawmills in Benin City. These were compared to 150 age and sex matched controls in order to determine the effect of sawdust exposure on the respiratory system. Questionnaire was used to elicit morbidity patterns and anthropometric measurements were also made. Respiratory rates, Peak Expiratory Flow Rates and Blood Pressures were measured in both groups. Respiratory symptoms were more common among sawmill workers compared to the controls. Smoking by some of these workers further aggravated their respiratory symptoms. Although blood pressure was similar in both groups, Respiratory rates were higher and Peak Flow Rates were lower in the sawmill workers compared to the controls $(20.83 \pm 2.02$ cycles/minute and $516.72 \pm 38.48 \mathrm{~L} /$ minute for the sawmill workers; $15.45 \pm$ 1.23 cycles/minute and $575.37 \pm 27.34 \mathrm{~L} /$ minute for the controls, respectively). Less than $5 \%$ of the sawmill workers wore protective devices/clothing, and health and safety standards were neither practiced nor enforced. The findings suggest that respiratory symptoms especially sputum production and chest pain are common in sawmill workers. Respiratory function is compromised in these workers.

Key Words: Respiratory symptoms, smoking, sawmill workers.

\section{Introduction}

Since the dawn of civilization, industries have been established to meet various human needs. Over the course of time, some of these industries were found to exert untoward effects on the health of man. Today, occupational lung diseases form an important branch of respiratory medicine. As knowledge increases so also is the awareness about the quality of life enjoyed by the workers. This has led to the determination of the health status of these workers.

Occupational toxicant exposures have an important role in many cases of lung diseases seen in workers (Kuschener and Stark, 2003). In Nigeria, various studies have shown the role of occupational exposure to environmental pollutants in the incidence of respiratory diseases (Jinadu and Malomo, 1986; Alakija et al, 1990; Ige and Onadeko, 2000; Okojie et al, 2003; Ijadunola et al, 2004; Okwari et al, 2005). Cough, sputum production and breathlessness are some of the reported respiratory symptoms in these workers, while occupational asthma (Rastogi et al, 1989), and hypersensitivity pneumonitis (Brooks et al,
1981) are recognized clinical syndromes common in such workers. The overall effect of these is a lower level of lung function in these workers.

Timber processing factories (sawmills) abound in Benin City which is located in the forest zone, because of the availability of timber in the zone. They are all privately owned. Wood dust (sawdust), a by-product of timber processing, is found in abundance in the sawmill industry, where it constitutes an occupational hazard. The Factories Act of Nigeria (1987) was designed to protect workers, as the legislations make provisions for the health safety and welfare of workers. Although modeled after that of Britain, unfortunately, government is not enforcing the laws for various reasons such as insufficient manpower for enforcement. Factory inspectors are very few (Asogwa, 2000).

This study was therefore carried out to determine the effect of sawdust exposure on the respiratory system which was assessed based on symptoms and measurement of the respiratory rate (RR) and Peak Expiratory Flow Rate (PEFR). The subjects used were 
classified into smokers and non smokers, since this difference has not been emphasized by previous workers in this locality. Information obtained from the study will help to further assess the degree of assault on the respiratory system, and then recommend appropriate preventive measures that would ensure a more healthy workforce.

\section{Methods}

The study was carried out in Benin, a metropolitan city that serves as the capital of Edo State. There are forty registered sawmill factories located in various parts of the city. They are all privately owned and belong to a central regulatory body, Edo State Forest Resources Management Association. Ethical approval for the study was obtained from the University of Benin Teaching Hospital medical ethics committee.

150 sawmill workers were selected by a 2 stage random sampling technique using a table of random numbers, from among the sawmill factories in Benin City. The first stage involved the random selection of 12 sawmills from the sawmill factories that were registered with the central regulatory body. The second stage involved the random selection of workers from the selected sawmills. Inclusion criteria in the study were workers between the ages of 18 and 50 years, and those who had spent at least one year in continuous employment at the sawmill factory.

150 age matched controls with similar socioeconomic background as the subjects were used. They were not employed in or resident close to any sawmill or dusty environment. They consisted of minibus drivers, vehicle technicians and auto electricians. Therefore, a total of 300 subjects and controls were studied after obtaining informed consent. They were all interviewed with the modified Medical
Research Council Questionnaire on respiratory symptoms (1960). Respondents answered questions on health status and smoking habits. Anthropometric measurements were made before the measurement of blood pressure (BP), respiratory rate (RR) and peak expiratory flow rate (PEFR). Statistical analysis of data was done using the EPI INFO for version 2002 (centre for disease control, Atlanta, Georgia, U.S.A). Statistical significance was set at $\leq 0.05$ for all values of the $t-$ test and chi - square test.

\section{Results}

Respondents were generally comparable in their demographic characteristics. (Table 1). There was no significant difference between the sawmill workers and the controls in terms of age, height, weight, blood pressure and duration of present employment.

Table 2 shows the prevalence of respiratory symptoms among the two groups. The sawmill workers had a significantly higher prevalence of respiratory symptoms compared to the controls. It is of note that shortness of breath with wheeze and chest tightness, though recorded among the sawmill workers, failed to reach statistical significance. Hemoptysis was not recorded in both groups. 131 sawmill workers $(87.6 \%)$ reported at least one respiratory symptom, compared with 28 among the controls. $(\mathrm{P}<0.05)$. Assessment of the prevalence of symptoms by smoking category showed that the sawmill workers had a significantly higher prevalence of all symptoms. (Tables 3 and 4). Statistical significance was however not obtained for shortness of breath with wheeze and chest tightness. Although 4 controls $(2.4 \%)$ reported chest pain among the non-smokers, this was not significant and all the sawmill workers who smoked reported chest pain.

Table 1: Demographic Characteristics of Sawmill Workers and Controls

\begin{tabular}{lccc}
\hline \multicolumn{1}{c}{ Study Parameter } & $\begin{array}{c}\text { Sawmill } \\
\text { workers }\end{array}$ & $\begin{array}{c}\text { Controls } \\
\mathrm{N}=150\end{array}$ & P Values \\
& $\mathrm{N}=150$ & & \\
Age (years) & $33.08 \pm 7.3$ & $32.9 \pm 7.2$ & $\mathrm{NS}$ \\
Height (cm) & $168.6 \pm 5.5$ & $168.7 \pm 5.5$ & $\mathrm{NS}$ \\
Weight (kg) & $69.82 \pm 5.9$ & $70.02 \pm 6.1$ & $\mathrm{NS}$ \\
Duration of present & $6.8 \pm 2.9$ & $6.9 \pm 3.5$ & $\mathrm{NS}$ \\
employment (years) & & & \\
Systolic BP (mmHg) & $122.7 \pm 11.1$ & $122.36 \pm 11.02$ & $\mathrm{NS}$ \\
Diastolic BP (mmHg) & $71.9 \pm 10.0$ & $71.4 \pm 9.9$ & $\mathrm{NS}$ \\
Number of smokers & 64 & 11 & $<0.05$ \\
\hline
\end{tabular}


Smoking and lung function in sawmill workers.

Table 2: Prevalence of respiratory symptoms among sawmill workers And controls

\begin{tabular}{|c|c|c|c|}
\hline Symptoms & $\begin{array}{c}\text { Sawmill workers } \\
N=150\end{array}$ & $\begin{array}{l}\text { Controls } \\
\mathrm{N}=150\end{array}$ & $\begin{array}{c}\mathrm{P}- \\
\text { Values }\end{array}$ \\
\hline Sputum production & $82(54.7 \%)$ & $13(8.7 \%)$ & $<0.05$ \\
\hline Cough & $52(34.7 \%)$ & $13(8.7 \%)$ & $<0.05$ \\
\hline Breathlessness & $14(9.3 \%)$ & $0(0 \%)$ & $<0.05$ \\
\hline Wheeze & $6(4 \%)$ & $0(0 \%)$ & $<0.05$ \\
\hline $\begin{array}{l}\text { Shortness of breath with } \\
\text { wheeze }\end{array}$ & $1(0.7 \%)$ & $0(0 \%)$ & NS \\
\hline Chest pain & $63(42 \%)$ & $3(2 \%)$ & $<0.05$ \\
\hline Chest tightness & $1(0.7 \%)$ & $0(0 \%)$ & NS \\
\hline Hemoptysis & $0(0 \%)$ & $0(0 \%)$ & NS \\
\hline $\begin{array}{l}\text { At least one respiratory } \\
\text { symptom }\end{array}$ & $131(87.3 \%)$ & $\begin{array}{c}28 \\
(18.7 \%)\end{array}$ & $<0.05$ \\
\hline
\end{tabular}

From Figure 1, the mean PEFR values obtained for each group were within the normal range. These values were $516.72 \pm$ $38.48 \mathrm{~L} / \mathrm{min}$. and $575.37 \pm 27.34 \mathrm{~L} / \mathrm{min}$. for the sawmill workers and the controls, respectively. However, the sawmill workers had significantly lower mean PEFR measurements compared with the controls. (P $<0.05$ ). Among the non-smokers (Table 5), the sawmill workers again had significantly lower mean PEFR values compared with the control group $(524.93 \pm 31.65 \mathrm{~L} / \mathrm{min}$. and $577.01 \pm$ $27.68 \mathrm{~L} / \mathrm{min}$. respectively). $(\mathrm{P}<0.05)$. The same findings were noted for smokers (Table 6). Respiratory rate measurements show clearly that the sawmill workers had a higher mean respiratory rate than the controls $(20.83$ \pm 2.02 cycles $/ \mathrm{min}$. and $15.45 \pm 1.23$ cycles/min. respectively), and this difference was statistically significant.

Table 3: Prevalence of respiratory symptoms among sawmill workers and controls by smoking status. (non-smokers)

\begin{tabular}{|c|c|c|c|}
\hline Symptoms & $\begin{array}{c}\text { Sawmill } \\
\text { workers } \\
\mathrm{N}=86\end{array}$ & $\begin{array}{l}\text { Controls } \\
\mathrm{N}=139\end{array}$ & P - Values \\
\hline Sputum production & $68(79 \%)$ & $30(21.6 \%)$ & $<0.05$ \\
\hline Cough & $46(53.5 \%)$ & $6(4.3 \%)$ & $<0.05$ \\
\hline Breathlessness & $11(12.8 \%)$ & $0(0 \%)$ & $<0.05$ \\
\hline Wheeze & $4(4.7 \%)$ & $0(0 \%)$ & $<0.05$ \\
\hline $\begin{array}{l}\text { Shortness of breath with } \\
\text { wheeze }\end{array}$ & $1(1.2 \%)$ & $0(0 \%)$ & NS \\
\hline Chest pain & $0(0 \%)$ & $4(2.9 \%)$ & NS \\
\hline Chest tightness & $1(1.2 \%)$ & $0(0 \%)$ & NS \\
\hline Hemoptysis & $0(0 \%)$ & $0(0 \%)$ & NS \\
\hline $\begin{array}{l}\text { At least one respiratory } \\
\text { symptom }\end{array}$ & $68(79 \%)$ & $30(21.6 \%)$ & $<0.05$ \\
\hline
\end{tabular}

Table 4: Prevalence of Respiratory Symptoms among Sawmill Workers and Controls by Smoking Status. (Smokers)

\begin{tabular}{|c|c|c|c|}
\hline Symptoms & $\begin{array}{c}\text { Sawmill } \\
\text { workers } \\
\mathrm{N}=64\end{array}$ & $\begin{array}{l}\text { Controls } \\
\mathrm{N}=11\end{array}$ & P - Values \\
\hline Sputum production & $47(73.4 \%)$ & $1(9.1 \%)$ & $<0.05$ \\
\hline Cough & $25(39.1 \%)$ & $1(9.1 \%)$ & $<0.05$ \\
\hline Breathlessness & $8(12.5 \%)$ & $0(0 \%)$ & $<0.05$ \\
\hline Wheeze & $4(6.3 \%)$ & $0(0 \%)$ & $<0.05$ \\
\hline $\begin{array}{l}\text { Shortness of breath with } \\
\text { wheeze }\end{array}$ & $1(1.6 \%)$ & $0(0 \%)$ & NS \\
\hline Chest pain & $64(100 \%)$ & $0(0 \%)$ & $<0.05$ \\
\hline Chest tightness & $1(1.6 \%)$ & $0(0 \%)$ & NS \\
\hline Hemoptysis & $0(0 \%)$ & $0(0 \%)$ & NS \\
\hline $\begin{array}{l}\text { At least one respiratory } \\
\text { symptom }\end{array}$ & $64(100 \%)$ & $2(3.1 \%)$ & $<0.05$ \\
\hline
\end{tabular}


Table 5: Peak Flow and Respiratory Rate among Sawmill Workers and Controls by Smoking Status. (Non-Smokers)

\begin{tabular}{lccc}
\hline Parameters & $\begin{array}{c}\text { Sawmill } \\
\text { workers } \\
\mathrm{N}=86\end{array}$ & $\begin{array}{c}\text { Controls } \\
\mathrm{N}=139\end{array}$ & $\begin{array}{c}\mathrm{P} \\
\text { Values }\end{array}$ \\
\hline Respiratory & 19.87 & 15.12 & $<0.05$ \\
rate & \pm 0.40 & \pm 1.79 & \\
PEFR & 524.93 & 577.01 & $<0.05$ \\
(1/min) & \pm 23.65 & \pm 18.68 & \\
Age (years) & 32.58 & 33.44 & $\mathrm{NS}$ \\
& \pm 8.14 & \pm 6.56 & \\
\hline
\end{tabular}

Table 6: Peak Flow and Respiratory Rate Among Sawmill Workers and Controls by Smoking Status. (Smokers)

\begin{tabular}{llll} 
Parameters & $\begin{array}{c}\text { Sawmill } \\
\text { workers } \\
\mathrm{N}=64\end{array}$ & $\begin{array}{c}\text { Controls } \\
\mathrm{N}=11\end{array}$ & $\begin{array}{c}\mathrm{P} \\
\text { Values }\end{array}$ \\
\hline Respiratory & 21.46 & 15.84 & $<0.05$ \\
rate & \pm 2.53 & \pm 1.12 & \\
PEFR & 513.40 & 574.87 & $<0.05$ \\
(1/min) & \pm 25.56 & \pm 17.68 & \\
Age (years) & 33.21 & 32.7 & $\mathrm{NS}$ \\
& \pm 2.35 & \pm 7.6 & \\
\hline
\end{tabular}

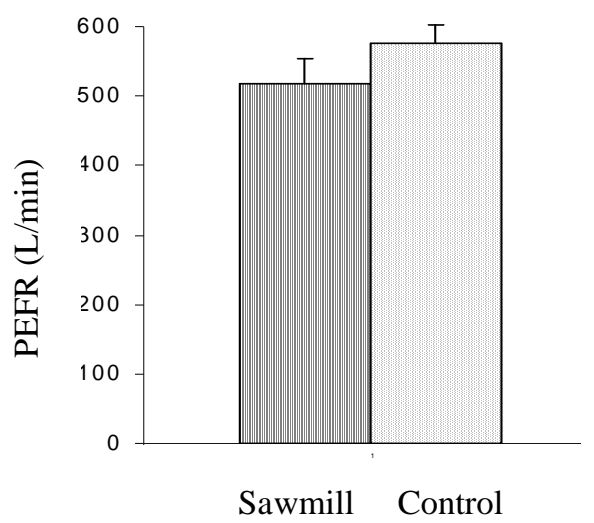

Fig. 1: PEFR in sawmill worker and control

\section{Discussion}

The lack of an organized occupational health service in the sawmill industry and ignorance on the part of the workers have resulted in their being exposed to hazards that have grievous consequences on their health.

Although there was no significant difference in blood pressure between the sawmill workers and the control populations, there was however a significant increase in the smoking population among the sawmill workers compared to the controls. This has not been observed in previous studies. This could be attributed to the fact that some of the sawmill workers ignorantly believe that smoking helps to eliminate sawdust from the lungs.

The results of this study have shown that sawmill workers in Benin City are at an increased risk of developing respiratory disorders compared with control subjects. This is in agreement with the studies of Fatusi and Erhabor (1996), Ige and Onadeko (2000), Douwes et al (2001), Okojie et al (2003) and Okwari et al (2005). The risk is even higher in sawmill workers who smoke. Although the prevalence of cough (34.8\%) among the sawmill workers in this study was comparable to that reported by Ige and Onadeko (2000), it was however lower than the $45.8 \%$ reported by Fatusi and Erhabor (1996). Sputum production of $55.3 \%$ among the sawmill workers in this study was higher than the $50.8 \%$ reported in the study by Fatusi and Erhabor (1996). While the prevalence of dyspnoea in this study was recorded as $9.6 \%$ among the sawmill workers, it was reported as $4.8 \%$ by Ige and Onadeko (2000) and $25.4 \%$ by Fatusi and Erhabor (1996). These differences probably relate to the degree of exposure of the airways to the sawdust.

Interestingly, chest pain was not a common symptom among non-smoking sawmill workers in this study. However virtually all the smoking sawmill workers had chest pain.

Among the sawmills visited in the course of this study, less than $5 \%$ of the workers wore face masks or protective clothing/boots. Another important reason for these findings is the type of wood processed. Most of the tree species processed in this environment are highly allergenic (International Labour Organization, 1972), such as Mansonia, Iroko and Walnut species. Some of the sawmill workers stated that they develop cough and increased sputum production a day or two after processing certain tree types such as Mansonia. Such tree species may contain high levels of irritant chemicals such as monoterpenes which have been shown to increase work related symptoms (Rosenburg et al, 2002). Another reason may be exposure to spores of molds, which are known to cause several respiratory symptoms and mucous membrane irritation among wood workers. (Edward et al, 1993; Dutkiewicz et al, 2001). The adverse effects of smoking on the respiratory system was highlighted by the fact that the prevalence of respiratory symptoms (especially chest pain) was higher in smokers than in the non-smokers among the study population. In addition to causing irritation of the respiratory tract, smoking provokes goblet cell hyperplasia and 
Smoking and lung function in sawmill workers.

impairs mucociliary clearance. The net effect of these changes are pulmonary endothelial damage (Bartel, 2001; Iyawe and Ebomoyi, 2005) which may provoke the above symptoms, in addition to the irritant effects of the sawdust on the respiratory system.

It is noteworthy that while the prevalence of cough and sputum production was quite high, those of the more disabling symptoms like breathlessness, wheeze and hemoptysis were low in the sawmill workers. This is however not a surprising finding, as subjects in this study, as in most cross sectional studies, might represent a survival population. So, the subjects who developed the more disabling symptoms might have changed jobs. Also, the observation that the prevalence of chest pain in these subjects was very high might be due to the very demanding physical nature of sawmilling. The prevalence of chest pain among sawmill workers who smoke is a major finding in this study, compared to previous studies.

The observation that the sawmill workers had lower Peak Flow Rate values and higher respiratory rates than the control groups may be due to the fact that since sawdust is not an inert particle, its chronic deposition in the lungs leads to alveolar thickening, resulting in chronic hypoxia from ventilation - perfusion imbalance. The body responds to this phenomenon by increased respiratory drive, resulting in the increased respiratory rates. The inflammatory changes in the respiratory tracts brought about by the sawdust exposure ultimately results in airway remodeling (Iyawe and Ebomoyi, 2005) and lung dysfunction. This invariably leads to increased airway resistance, which manifests as lower Peak Flow Rate values in the sawmill workers compared to the controls.

This study has shown that sawmill workers are at an increased risk of developing respiratory disorders compared to control subjects, and this risk is even more pronounced in a situation where the sawmill worker is also a smoker. Although the sawmill factories were heavily sawdust polluted, the vast majority of the workers wore no face masks or other protective devices. Employers and employees need to be adequately educated about the need to take necessary control measures. Government, corporate organizations and international agencies should assist medium and small scale industrialists by making modern equipments that could be operated with minimal health hazards as in the developed countries. It is necessary to set out legislation that must be enforced in order to protect the health of these workers, that constitute a major portion of the private sector workforce in Benin City.

References

Alakija, W., Iyawe, V. I., Jarikre, L. N., Chiwuzie, J. C. (1990). Ventilatory function of workers at Okpella cement factory in Nigeria. West Afr. J. Med. 9 (3): $187-191$.

Asogwa, S. E. (2000). Guide to Occupational Health Practice in Developing Countries. $\quad 2^{\text {nd }}$ edition. Fourth Dimension Publishers. 89.

Bartel, M. (2001). Health effect of Tobacco use and exposure. Monaldi Archives of Chest Diseases. 56: 545-550.

Brooks, S. M., Edwards, J. J., Agol, A., Edwards, F. H. (1981). An epidemiologic study of workers exposed to western red cedar and other wood dusts. Chest; 80: $305-325$.

Douwes, J., Mc Lean, D., Slater, T., Pearce, N. (2001). Asthma and other respiratory symptoms in New Zealand pine processing sawmill workers. American Journal of Industrial Medicine; 39 (6): $608-615$

Dutkiewicz, J., Skorska, C., Dutkiewicz, E., Matuszyk, A. (2001). Response of sawmill workers to work related airborne allergens. Annals of Agric. Environ. Med.. 8 (1): 81 - 90.

Edward, W., Sandveu, P., Levy, F. (1993). Serum IgG antibodies to Mold spores in two Norwegian sawmill populations; relationship to respiratory and other work related symptoms. Am. J. Ind.. Med. 24 (2): $207-222$.

Fatusi, A, Erhabor, G. (1996). Occupational health status of sawmill workers in Nigeria. J. Royal Soc. Health. 116 (4): $232-236$.

Federal Republic of Nigeria. (1987). Factories Act No.16. Gazette A95 - 124. Government Printing Press, Lagos.

Ige, O. M., Onadeko, O. .B. (2000). Respiratory symptoms and ventilatory function of the sawmillers in Ibadan, Nigeria. Afr. J. Med. Med. Sci. 29 (2): $101-104$.

Ijadunola, K. T., Erhabor, G. E., Onajade, A. A., Ijadunola, M.V, Fatusi, A.O, Asuzu, M.C. (2004). Prevention of respiratory symptoms among wheat flour mill workers in Ibadan, Nigeria. Am. J. Ind. Med.45: 251 - 259.

International Labour Organization (ILO) (1972). Encyclopedia of Occupational Health and Safety. 2: 1507 - 1508.

Iyawe, V.I. and Ebomoyi, M.I. (2005). Current developments in the physiology and 
management of asthma. Nig. J. Physiol. Sci. 20: 19-29.

Jinadu, M.K, Malomo, M.O. (1986). Investigation into occupational health problems of bakery workers in Ile-Ife, Nigeria. Nig. Med. Practitioner 12 (3): $39-41$.

Kuschener, W.G, Stark, P. (2003). Occupational toxicant exposures have an important role in many cases of lung diseases seen in workers. Occupational Lung Disease. Part 1. Identifying workrelated asthma and other disorders. Postgrad. Med. 113 (4):70 - 78.

Medical Research Council Committee on the aetiology of Chronic Bronchitis.(1960). Standard questionnaire on respiratory symptoms. Br. Med. J.2: $1665-1668$.

Okojie, O.H, Egbagbe, E, Kadiri, I. (2003). An epidemiological study of the health status of sawmill workers in Benin City,
Edo State, Nigeria. J. Med. Biomed. Res. 2 (1): $76-81$.

Okwari, O.O, Antai, A.B, Owu, D.U, Peters, E.J, Osim, E.E. (2005). Lung function status of workers exposed to wood dust in timber markets in Calabar, Nigeria. Afr. J. Med. Med. Sc. 34: $141-145$.

Rastogi, S.K, Gupta, B.N, Hasain, T, Mathus, N. (1989). Respiratory health effects from occupational exposure to wood dust in sawmills. Am. Ind. Hygiene Assoc. J. 50: 574 - 578.

Rosenburg, C, Liukkonen, T, Kallas-Tarpila, T, Rounakangas, A. (2002). Monoterpenes and wood dust exposures: work - related symptoms among sawmill workers. Am. J. Ind. Med..41(1):38-53.

Received: $23 / 8 / 06$

Accepted: $3 / 11 / 06$ 